\title{
印象情報付きPCAによる日本人とタイ人間の人種的顔特徵の 抽出
}

\section{Use of PCA with Information on Impressions to Extract of Racial Facial Feature Between Images of Japanese and Thai Faces}

\author{
正会員 秋 葉 将 和†, \\ チャロトーンリュウチャワリットけ†， \\ 正会員 菅野 恒 雄 ${ }^{\dagger}$, 正会員 長 尾智 晴姑
}

Masakazu Akiba ${ }^{\dagger, \dagger}$, Chalothorn Liewchavalit"it, Tsuneo Kanno ${ }^{\dagger}$ and Tomoharu Nagao

\begin{abstract}
We used facial images of racially close group such as Japanese and Thais to study which features affect the viewer's impression of ethnicity. Principle component analysis (PCA) was done to extract the racial features of the sample group. The facial features were separated into information on texture and shape, and the PCA was applied to each. We compared the basic with the weighted PCA with the score related to impression of race. The racial impression score was provided by a psychological experiment. A weighted PCA with information of the user's impression extracted racial facial features from an image that had fewer cues to ethnicity because of changed facial direction and reduced lighting. The extracted features of texture and shape could be used for the racial impression conversion of facial images. We suggest that the identification of features typical of a given race relies on detailed texture rather than shape.
\end{abstract}

キーワード：顔，人種，印象，特徵抽出，PCA，タイ人，日本人

\section{1. まえがき}

我々はこれまで，同じアジア人であり，人種的に近い日 本人とタイ人の顔画像を用いて，人種および性別認知の特 徵を心理実験によって検討してきた ${ }^{122}$ ，具体的には，色や 髪形の情報を除いた顔画像から被験者がどの程度の確率で 人種を識別し，これが被験者および顔画像の人種や性別に よって差があるのか, 顔画像から人種や性別を認識する際 にどの部分に注目し，どの部分が印象を決める要因になる のか，などの点について着目し検証を行ってきた。これら の研究で, 人種識別能力は学習によって向上すること, 目 と眉が日本人とタイ人を識別する重要な手掛かりとなって いることなどが明らかになった。しかし，顔の人種的印象 を決定づける各部位の詳細な特徵については検討に至って

2010 年 10 月 15 日受付, 2011 年 1 月 24 日再受付, 2011 年 3 月 3 日採録 †職業能力開発総合大学校情報システム工学科

（率 252-5196 神奈川県相模原市緑区橋本台 4-1-1, TEL 042-763-9005)

$\dagger$ 横浜国立大学大学院 環境情報学府

（＝240-8501 神奈川県横浜市保土ケ谷区常盤台 79-7, TEL 045-339-4136） 十†夕イ労働省技能開発局

(Mitmaitree Road, Din Daeng, Bangkok, 10400, Thailand)

$\dagger$ Information Systems Engineering Depatment, Polyechnic University

(4-1-1, Hasimotodai,Sagamiharasi,252-5196,Japan)

$\uparrow$ Graduate School of Environment and Information Sciences, Yokohama National University

(79-7, Tokiwadai, Hodogaya-ku, Yokohama, 240-8501,Japan)

$\dagger \uparrow$ Department of Skill Development, Ministry of Labour, Thailand (Mitmaitree Road, Din Daeng, Bangkok, 10400, Thailand)
いなかった。

一方, 顔画像の認識手法の一つとして, 多数の顔パター ンの集合に対して, 統計的特徴抽出法として知られた PCA を適用する手法がある．TurkらはPCAによって得られた固 有ベクトルから固有顔と呼ばれる正規直交基底を求め，こ こから識別のための特徴ベクトルを求める手法で, 高い個 人認識率を得た ${ }^{3)}$ 。この手法は顔画像認識や顔特徵抽出等 に広く利用されている。

近年，人間が顔から受ける様々な印象と顔の物理的特徵 との因果関係を探る研究や, 顔印象操作などの工学的な応 用も含めた多くの研究が行われている. 向田らは，みかけ の年龄に影響を及ほす顔形状特徵をPCAによって抽出し ている ${ }^{4)}$. 深田らは顔の形状情報について SVM と PCA を 組合せた解析を行い，年代ごとの魅力顔の特徴について解 析・印象操作を行う手法について報告している ${ }^{5)}$. 小林ら は顔画像の形状情報とテクスチャ情報にPCA を適用し，こ の結果に線形判別分析を施し年齢・性差などの印象変換べ クトルを生成する手法を提案しているの.

顔画像から人種を自動推定する研究も行われているが, モンゴロイド，コーカソイド，ネグロイドの 3 大人種によ る分類であり，遺伝的に近い人種による分類は行われてい ない7?. 顔画像から人種を推定する技術は，顔を認知し案 内板に表示する言語を自動的に切り換えるシステムなどへ の応用も考えられる。また，人間が感じる顔印象と顔特徵 
との因果関係を分析することは，印象語をキーワードとし た顔画像検索システムへの応用などに示唆を与えることに もなる。

本研究では，同じアジア人であり人種的に近い日本人と 夕イ人の顔画像を用いて, 日本人と夕イ人の人種的印象に 影響を及ぼす顔特徵の違いをPCAによって抽出・分析した. 具体的には，顔特徴をテクスチャ情報と形状情報に分離し， それぞれについて心理実験による人種印象評価と関連する 特徴をPCAによって抽出・分析した.PCAによる特徵抽 出では, 従来法と向田らが提案した属性值付加 PCA による 手法を比較検討した，向田らは，顔の形状情報にみかけの 年齢情報を付加して属性值付加 PCA を行ったが, 従来法と の比較や得られた主成分に関する詳細な検討, テクスチヤ に対する適用は行われていない。本研究では，形状情報お よびテクスチャ情報それぞれについて属性值付加 PCAを行 い，人種印象に影響を及ぼす顔特徽について検討した。さ らに, 抽出された特徴を用いて人種印象変換操作を行った. 従来の PCA による顔特徵抽出において, 顔特徴として 得られた主成分には各部位の形状や配置の違い, 皮膚のひ た，体毛の濃さなどのほかに，照明による影響や顔向きの 微妙な違いによる特徵も混在していた。本研究で行った形 状情報とテクスチャ情報を分離した属性值付加 PCA によっ て，照明や顔向きによる影響を軽減し，人種印象に関わる 顔特徴成分に特化した主成分を抽出できた。

\section{2. 日本人とタイ人の顔特徵}

本報告では,「日本人」を「日本列島に居住した集団を祖 先に持ち, 遺伝子組成の基層を共有する集団」と定義し, こ のような意味で「日本人」という言葉を用いる。日本人の 起源に関しては様々な議論があるが, 縄文系と渡来系の二 重構造説がよく知られている ${ }^{8)}$. 縄文系集団は東南アジア を源流とする南方モンゴロイド的特徵を多く有し, 渡来系 集団は北東アジアから渡来し, 寒冷地適応した北方モンゴ ロイドの特徵を有していたといわれる。そのため, 現代日 本人の顔は, 縄文人夕イプと渡来人夕イプおよびその中間 タイプがあり, 全体としては渡来系 (北東アジア系) の影 響が強いといわれている ${ }^{9}$. 北東アジア系の顔の特徵とし ては, 平たい顔, 張り出した煩骨, 明るい皮膚色, 薄いひ げ，蒙古ひだおよび一重まぶたなどがあげられる。

一方, 東南アジア地域には国家を形成するいくつかの大 民族のほか，多数の少数民族が分布している。これらの民 族は，ほとんどすべて人種的にはモンゴロイド大人種の南 方群に属する。タイ国は総人口の約 $85 \%$ タイ族が占め, その他中国系，マレー系，インド系，カンボネシア系を中 心に様々な民族で構成されている ${ }^{10)}$ 。民族間の混血は進ん でおり，とりわけ都市において中国系住民との混血が多い. 東南アジア系の顔の特徴としては, 黄褐色ないし褐色の皮 膚色, 丸顔だがやや彫りが深く, 平たい鼻と大きな鼻孔, 二 重まぶたなどがあげられる ${ }^{11}$.

\section{PCA による顔特徵抽出}

\section{1 顔画像のベクトル表現}

顔は共通の構造を持つが, 複雑で微妙な形状の違いがあ る.顔画像集合から正確な特徵抽出を行うためには, 顔の 形状を表す特徴点を設定し，これらの特徴点を基準として， 異なる顔画像間での画素の対応付けを行う必要がある。本 研究では, 特徴点座標值から構成される形状情報と, 画素 の対応が付くように同一形状に正規化されたテクスチャ情 報を用いて，顔特徴の抽出・分析を行う.

形状べクトルは, 顔特徵点の $x y$ 座標值を 1 列に並べたべ クトルとして定義され，顔の各部位の配置やおおまかな輪 郭を表す。平均形状は顔画像集合の特徴点座標値を算術平 均することによって得られる.テクスチャベクトルは, 各顔 画像を平均形状ヘワーピング (画像変形) して得られる画 像の濃淡值から成るべクトルとして定義される。以降, こ れを正規化テクスチャと呼ぶ. 正規化テクスチャは，2次 元の形状情報では正規化しきれない顔の凹凸による濃淡值 の差や，眉などの体毛の濃さ，皮膚のひた，目・鼻・口な どの各部位が持つ微細な違いを表す.

\subsection{PCA(Principal Component Analysis)}

PCA(主成分分析) は多変量デー夕を縮約し，より低次元 の変量によって元のデータの特性を表現するための多変量 解析手法である。本研究では，このPCAの手法を顔形状 ベクトルと正規化テクスチャそれぞれに適用し, 顔の特徴 を検討する。

PCA による次元圧縮は次のように定式化できる。 $N$ 枚 の顔画像のうち $i$ 番目の顔画像の形状べクトル（または正 規化テクスチヤ）を $\boldsymbol{x}_{i}$ とする. $\mathrm{M}$ 次元べクトル $\boldsymbol{x}_{i}$ の要素 $p_{i}^{m}(m=1, \cdots, M)$ は, 形状べクトルにおいては顔形状特徵 点の $x y$ 座標值であり, 正規化テクスチャにおいては顔画像 テクスチャの濃淡值である. 平均べクトル $\overline{\boldsymbol{x}}=\frac{1}{N} \sum_{i=1}^{N} \boldsymbol{x}_{i}$ を 求め，共分散行列 $\boldsymbol{R}$ を式 (2)によって求める.

$$
\begin{aligned}
\boldsymbol{x}_{i} & =\left[p_{i}^{1}, p_{i}^{2}, p_{i}^{3}, \cdots, p_{i}^{M-1}, p_{i}^{M}\right]^{T} \\
(i & =1, \cdots, N) \\
\boldsymbol{R} & =\frac{1}{N} \sum_{i=1}^{N}\left(\boldsymbol{x}_{i}-\overline{\boldsymbol{x}}\right)\left(\boldsymbol{x}_{i}-\overline{\boldsymbol{x}}\right)^{T}
\end{aligned}
$$

行列 $\boldsymbol{R}$ について式 (3)(4) を満足する固有べクトル $\boldsymbol{u}_{k}$ とそ れに対応する固有值 $\lambda_{k}$ を求める.

$$
\begin{aligned}
\boldsymbol{R} \boldsymbol{u}_{k} & =\lambda_{k} \boldsymbol{u}_{k} \quad\left(\lambda_{1} \geqq \lambda_{2} \cdots \geqq \lambda_{N-1}\right) \\
\boldsymbol{u}_{k}^{T} \boldsymbol{u}_{k} & =1 \\
(k & =1, \cdots, N-1)
\end{aligned}
$$

本研究では，形状べクトル集合から求められる $\boldsymbol{u}_{k}$ を第 $k$ 主 成分固有形状，正規化テクスチャ集合から求められる $\boldsymbol{u}_{k}$ を 第 $k$ 主成分固有テクスチャと呼ぶことにする。この固有べ クトル $\boldsymbol{u}_{k}$ は標本集合の正規直交基底となっており，任意 
の標本ベクトル $\boldsymbol{x}_{i}$ は $\boldsymbol{u}_{k}$ の線形結合として式 (5) で近似で きる。

$$
\begin{array}{r}
\boldsymbol{x}_{i} \simeq \sum_{k=1}^{L}\left(y_{k}^{(i)} \boldsymbol{u}_{k}\right)+\overline{\boldsymbol{x}} \\
(1 \leqq L \leqq N-1)
\end{array}
$$

このとき, $\boldsymbol{x}_{i}$ の第 $k$ 主成分に対する主成分スコア $y_{k}^{(i)}$ は式 (6)で表せる.

$$
\begin{aligned}
y_{k}^{(i)} & =\boldsymbol{u}_{k}^{T}\left(\boldsymbol{x}_{i}-\overline{\boldsymbol{x}}\right) \\
(k & =1, \cdots, L ; i=1, \cdots, N)
\end{aligned}
$$

式 (6) によって求められる $y_{k}^{(i)}$ を成分とする $L$ 次元べクト ル $Y_{i}$ が，任意の標本べクトル $\boldsymbol{x}_{i}$ の $L$ 次元に圧縮された特 徵べクトルとなる。

$$
\boldsymbol{Y}_{i}=\left(y_{1}^{(i)}, \cdots, y_{L}^{(i)}\right)
$$

また，第 $k$ 主成分の固有值 $\lambda_{k}$ と主成分スコアの標準偏差 $\sigma_{k}$ の関係は式 (8) で表せる.

$$
\sigma_{k}^{2}=\lambda_{k}
$$

\section{3 主成分特徵の検討}

本研究では, 形状ベクトルと正規化テクスチャそれぞれ について, 得られた固有べクトルから第 $k$ 主成分の特徵を 検討する．第 $k$ 主成分固有べクトルの正方向または負方向 の変化を強調した顔特徵べクトルを式 (9)(10)によって求め る. $q$ は強調の程度を表す重み係数である. $\boldsymbol{g}_{k}^{(+)}$と $\boldsymbol{g}_{k}^{(-)}$を顔 パターンとして視覚化し, 各主成分の特徴を比較検討する.

$$
\begin{aligned}
& \boldsymbol{g}_{k}^{(+)}=\overline{\boldsymbol{x}}+q \sigma_{k} \boldsymbol{u}_{k} \\
& \boldsymbol{g}_{k}^{(-)}=\overline{\boldsymbol{x}}-q \sigma_{k} \boldsymbol{u}_{k}
\end{aligned}
$$

\section{4 属性值付加 PCA}

向田らは, 顔特徵点の $x y$ 座標值を要素とする形状べクト ルにみかけの年齢属性の情報を付加し PCA を行った.この 実験で，向田らは年齢認知に影響を及ぼす顔形状特徵を第 1 主成分として抽出できたことを報告している ${ }^{4)}$ 。この手 法は，顔を表す $M$ 次元の観測べクトル $\boldsymbol{x}_{i}$ に，性別や年齢 などの属性を表す情報 $a_{i}$ を加えた $M+1$ 次元べクトル $\boldsymbol{x}_{i}^{\prime}$ を顔特徴べクトルとして用いる.

$$
\boldsymbol{x}_{i}^{\prime}=\left[p_{i}^{1}, p_{i}^{2}, p_{i}^{3}, \ldots, p_{i}^{M-1}, p_{i}^{M}, a_{i} \times \omega\right]^{T}
$$

式 (11) において， $\omega$ は属性值 $a_{i}$ に与える重み係数である. 重み $\omega$ を与えることで, 属性值 $a_{i}$ の分散を大きく設定す ることができる. PCA は分散最大となる軸を第 1 主成分と することから，重み $\omega$ を充分に大きく設定することによっ て, 属性值 $a_{i}$ に関連する特徽を第 1 主成分として抽出する ことができる。

本研究では, 顔の人種を評価する心理実験を行い, これ によって得られた人種評価得点を属性值情報 $a_{i}$ として付加 する. $M+1$ 次元べクトルの集合 $\boldsymbol{x}_{i}^{\prime}(i=1, \cdots, N)$ から共
分散行列 $\boldsymbol{R}^{\prime}$ を求め, 式 (3)(4) と同様に固有ベクトル $\boldsymbol{u}_{k}^{\prime}$ と それに対応する固有值 $\lambda_{k}^{\prime}$ を求める。重み $\omega$ を非常に大き くしていくことによって，第 1 主成分は人種評価得点の影 響を大きく受けた軸となり，第 1 主成分の寄与率，および， 第 1 主成分スコアと人種評価得点との相関も高くなる。た だし，固有ベクトル $\boldsymbol{u}_{k}^{\prime}$ は， $M+1$ 次元のベクトルであり， 属性值要素を含んでいる. 固有べクトルから顔特徴を分析 する場合は，属性值要素は不要であるため， $\boldsymbol{u}_{k}^{\prime}$ から $M+1$ 次元目の要素を除去した後，ノルム 1 に正規化した $\boldsymbol{v}_{k}$ を用 いることとする。このように人種評価得点を付加して求め られた $M+1$ 次元の第 1 主成分固有ベクトル $\boldsymbol{u}_{1}^{\prime}$ の $M$ 次元 空間への射影 $\boldsymbol{v}_{1}$ は, 人種的顔印象特徵を捉えた軸となって いることが予想される。本研究では， $v_{1}$ が人種的顔印象特 徴をどの程度表現できているかを評価する指標として，式 (12)によって主成分スコアを再計算し， $z_{1}^{(i)}$ の標準偏差，お よび， $z_{1}^{(i)}$ と $a_{i}$ との相関を求める. 式 (12)において $k$ は主 成分番号， $i$ は顔画像番号である。標準偏差が大きいほどよ り多くの情報量を含んでおり，相関係数の絶対值が大きい ほど人種評価との関連が強いといえる。

$$
\begin{aligned}
z_{k}^{(i)} & =\boldsymbol{v}_{k}^{T}\left(\boldsymbol{x}_{i}-\overline{\boldsymbol{x}}\right) \\
(k & =1, \cdots, N-1 ; i=1, \cdots, N)
\end{aligned}
$$

向田らは，顔の形状情報にみかけの年齢情報を付加して 属性值付加 PCA を行った。しかし，得られた主成分に関 する詳細な検討やテクスチャに対する適用は行っていない. 本研究では, 形状ベクトルおよび正規化テクスチャそれぞ れについて属性值付加 PCA を行い，人種の印象に影響を 及ぼす顔特徵について検討する。

\section{5 印象変換}

本研究では, 属性值付加 PCA の第 1 主成分から得られる ベクトル $\boldsymbol{v}_{1}$ を用いて，顔画像の人種印象変換操作を行う. 式 $(13)$ によって人種印象変換ベクトル $f$ を求める。 $h$ は変 換の程度を表す重み係数であり， $\sigma_{z 1}$ は式 (12)によって求 められる $z_{1}^{(i)}$ の標準偏差である.

$$
\boldsymbol{f}=h \sigma_{z 1} \boldsymbol{v}_{1}
$$

印象変換は，任意の顔画像の顔パターンベクトル $x_{i}$ に人種 印象変換べクトル $\boldsymbol{f}$ を加算または減算することによって行 う(式 (14)).

$$
s_{i}=x_{i} \pm f
$$

正規化テクスチャによる印象変換では元画像の正規化テク スチャ $\boldsymbol{x}_{i}$ に対して式 (14) を適用し，印象変換テクスチヤ $\boldsymbol{s}_{i}$ を求める.この $s_{i}$ を元画像の形状へ画像変形し印象変換画 像とする。形状べクトルによる印象変換では，元画像の形 状べクトル $\boldsymbol{x}_{i}$ に対して式 (14) を適用し，印象変換形状 $\boldsymbol{s}_{i}$ を求める. 元画像を $s_{i}$ の形状へ画像变形し印象变換画像と する．また，正規化テクスチャと形状べクトルの双方を用 いた印象変換は，印象変換テクスチャを印象変換形状へ画 


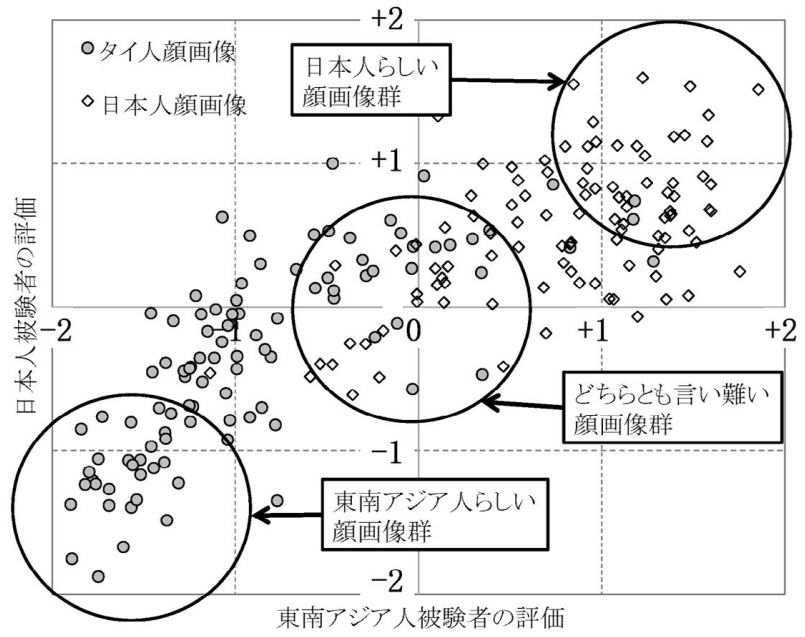

図 1 画像ごとの平均人種評価得点の分布

Distribution of racial score of each face.

像変形することによって行う.

\section{4. 実験用顔画像}

日本人男女と夕イ人男女の顔画像を各 50 枚づつ計 200 枚用意した。このうち日本人顔画像は, 財団法人ソフトピ アジャパンの顔画像データベースに含まれる正面顔 25 枚 と我々が独自に収集した 75 枚の画像であり，タイ人顔画像 は全て独自に収集した画像であった。顔画像の収集は，撮 影および実験使用許諾を得たうえで，正面からデイジタル カメラで撮影することによって行った。顔画像の人物はい づれも 10 代後半から 20 代半ばまでの年齢であって, 眼鏡 を着用している，鬍が目立つ，前髪が眉にかかるなどの画 像は含まれていない。

実験用顔画像としては，これらの正面顔画像の位置・大き さと濃度を正規化して用いた，位置・大きさの正規化は，両 目の位置㧍よび間隔が同じとなるよう補正を行った。画像 濃度は皮虐色の影響をなくすため，256 諧調グレースケー ルに変換後，皮膚色のグレーレベルが同程度になるようヒ ストグラム処理によって正規化した。

我々はこれまでの研究において，これら日本人と夕イ人 の顔画像を用いて人種および性別認知の特徵を心理実験に よって検討し, この人種認知実験の結果から, 各顔画像の 人種評価得点を算出している ${ }^{1)}$. 人種認知実験によって得ら れた平均人種評価得点の分布を図 1 に示す。平均評価得点 は- 2 + 2 の範囲で正方向に大きいほど日本人らしく，負 の方向に大きいほど東南アジア人らしい顔画像と評価され たことを意味する。

\section{5. 人種的顔印象特徵抽出実験}

\section{1 顔特徵ベクトルの定義}

本実験では，エージェント生成ツール FaceFit Ver.2 を用 いて，実験用顔画像の特徵点 137 点を目視で設定した。形 状ベクトルは，特徴点の $x y$ 座標值を 1 列に並べた 274 次元

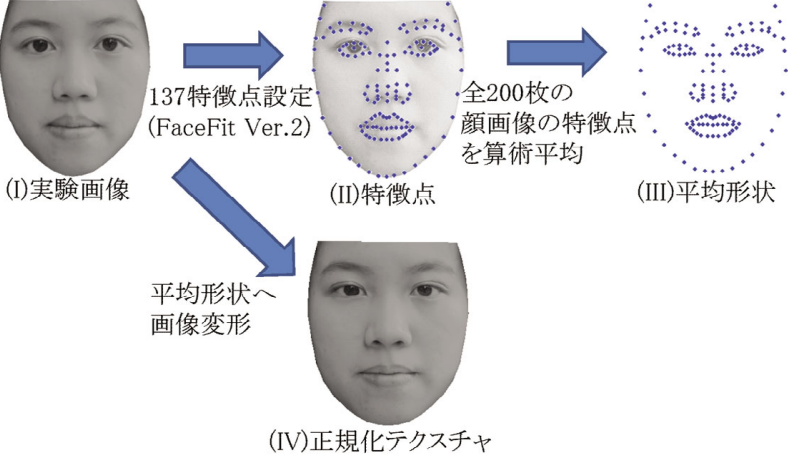

図 2 顔特徵ベクトル生成の流れ Flow of face feature vector generation.

ベクトルとして定義した．平均形状は全 200 枚の顔画像集 合の特徴点座標値を算術平均することによって求めた．正 規化テクスチヤは，各顔画像を平均形状へワーピング（画像 変形）して得られる $262 \times 300$ 画素の濃淡值から成る 78600 次元ベクトルとして定義した。図 2 に顔特徵ベクトル生成 の流れを示す。図 2(I) は実験顔画像の例であり, (II) は画 像 (I) の形状特徽点, (III) は平均形状の特徴点, (IV) は画 像 (I) を平均形状へワーピングした正規化テクスチャ画像 である。

\section{2 付加属性值の重み係数の検討}

3.4 節で述べた属性值付加 PCA を行う場合, 式 (11)の 重み $\omega$ を適当な值に決定する必要がある。向田らは重み $\omega$ をある程度大きな值に設定すればよいと提案している ${ }^{4)}$. 本 実験では，男性および女性顔画像集合それぞれについて $\omega$ の值を変化させ属性值付加 PCA を行い, 式 (12) によって $z_{1}^{(i)}$ を求め, これと付加属性值である人種評価得点 $a_{i}$ との 相関を求めた。人種評価得点は- $2 \sim+2$ の值をとるが，属 性值として付加する場合は，他要素と単位スケールを合わ せるために，最小值・最大值にて正規化して用いた。図 3 に正規化テクスチャ，図 4 に形状べクトルについての実験 結果を示す．重み $\omega$ を大きくしていくと， $z_{1}^{(i)}$ と人種評価 得点 $a_{i}$ の相関係数の絶対值は徐々に大きくなるが，一定值 以上には上がらない，そのため，重み $\omega$ の值はこの相関係 数値が充分収束する値として，正規化テクスチャにおいて $\omega=300$ ，形状べクトルに抏いて $\omega=10$ とした.

図 3 から正規化テクスチャ特徴においては女性の方が人 種評価得点との相関が高く, 図 4 から形状特徵においては, 男性の方が人種評価得点との相関が高いことがわかる。ま た，正規化テクスチヤ特徴と形状特徴では，正規化テクス チャ特徵の方が人種評価得点との相関が高い，女性におい てはテクスチャ特徴がより重要な人種印象特徵となってお り, 男性では人種印象における形状特徵の重要性が女性と 比較して相対的に高いと考えられる。

\section{3 テクスチャ特徵の抽出}

本実験では，男性顔画像（日本人，タイ人各 50 枚計 100 枚）と女性顔画像（日本人，夕イ人各 50 枚計 100 枚）を 分けて，それぞれの正規化テクスチャ集合に対して従来法 


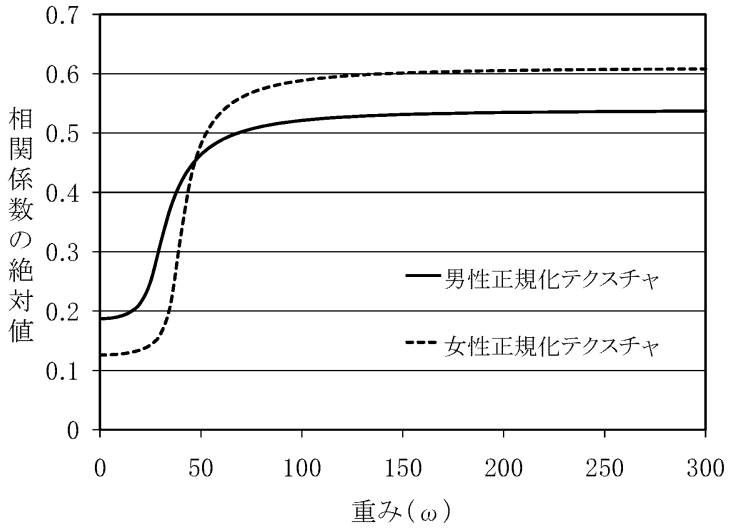

図 3 属性值付加 PCA に扔ける第 1 主成分スコア $z_{1}^{(i)}$ と人種評 価得点との相関（正規化テクスチャ）

Correlation coefficient of the 1st principal component scores(eq.12: $z_{1}^{(i)}$ ) and racial scores. (Normalized texture).

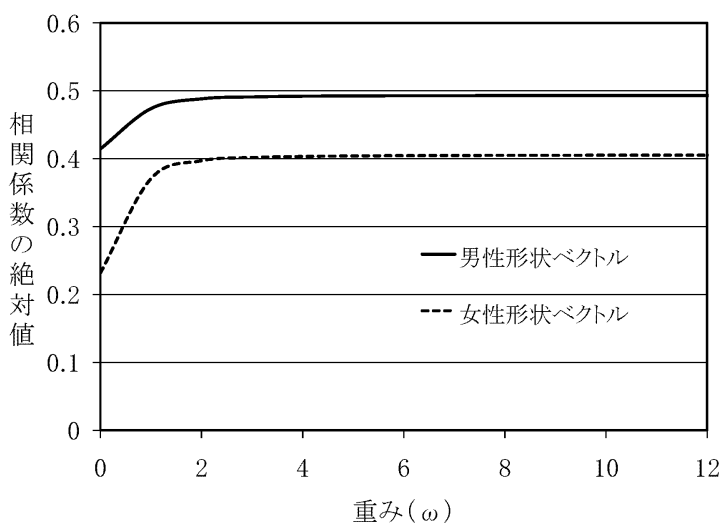

図 4 属性值付加 PCA に打ける第 1 主成分スコア $z_{1}^{(i)}$ と人種評 価得点との相関（形状ベクトル）

Correlation coefficient of the 1st principal component scores(eq.12: $z_{1}^{(i)}$ ) and racial scores. (Shape vector).

のPCA および属性值付加 PCA を適用し， 3.3 節で述べた 手法によって各主成分の特徽を検討した。 以降, 女性顔画 像集合からの特徵抽出を例に結果と考察を述べる.

\subsubsection{PCA によるテクスチャ特徵抽出}

図 5 は女性顔画像の正規化テクスチャ集合に対して，従 来法のPCA を適用して得られた固有テクスチャおよび特徴 強調画像である。PC No(1〜4) は主成分番号を示し，PV\% は寄与率， $\sigma_{k}$ は主成分スコアの標準偏差である。(a) は各 主成分に扔ける固有テクスチャであり，(b) は式 (9)，(c) は 式(10)に抏いて $q=4.0$ として求められた各主成分におけ る特徵強調画像，(d) は (b)(c) の差分画像である. (d) の差 分画像は, (b)(c) 画像間で濃度差が大きいほど明度が高く なる。

式 (9)(10) においては， $q$ の值を小さくしすぎると平均の 顔パターンに近づき, 各主成分で抽出された特徽を検討し づらい，qの值を大きくしすぎると，形状べクトルに適用 した際に顔として不自然な形状となる。そのため， $q=4.0$ は， $q$ の值を 0.5 刻みで変化させ生成した顔パターンを目 視で判断する予備実験の結果から, 特徵強調画像間の差を

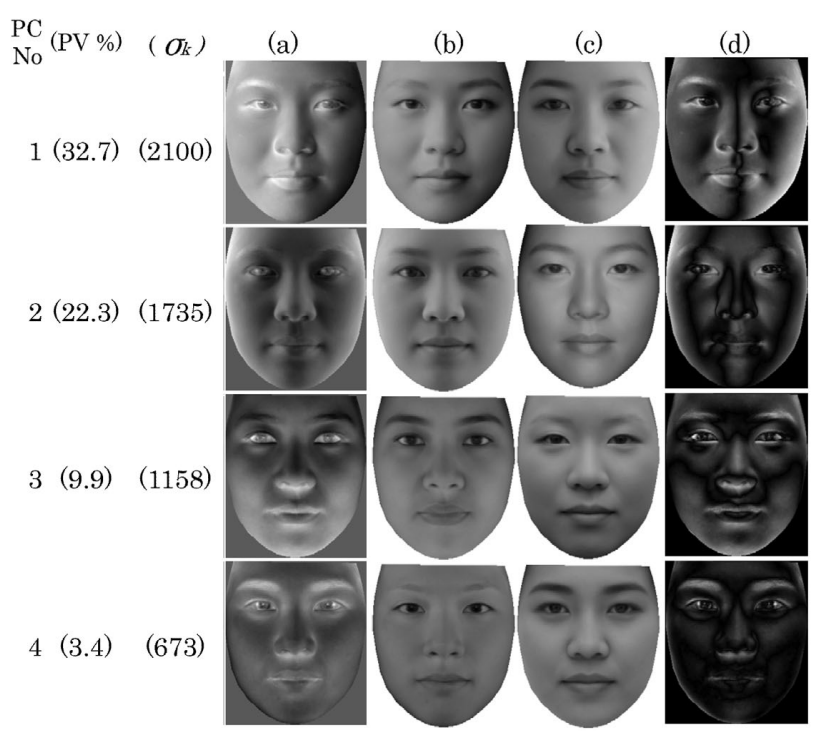

図 5 正規化テクスチャ(女性) の特徵 Feature of normalized texture. (female).

はっきりと認識でき，かつ，形状ベクトルに適用した際に 不自然な顔形状とならない值として採用した。以降，本研 究ではこの $q=4.0$ を用いて実験を行った.

本実験ではこれら図 5 中の (a) (d) の画像から各主成分 において抽出された特徵を検討した。

第 1 主成分の特徵 図 5 の第 1 主成分差分画像 (d) に おいて顔左右対称部分の明度が高いこと，顔中央部に明度 の低い縦のラインがみられることから, 特徵強調画像 (b)(c) 間では顔中央部を境界として左右の明度差が大きいことが わかる，また，画像 (b)(c) に扔いて陰影の付き方が左右逆 であることを主観的に判断できる。これらの点から，第 1 主成分は左右照明の違いによる除影の特徵を多く抽出して いると考えられる。

第 2 主成分の特徵 図 5 の第 2 主成分差分画像 (d) に 扔いて顔中央付近と顔輪郭部分に明度が高い箇所が分かれ ていること，画像 (b)(c) の陰影の特徴などから，正面また は後方からの照明の違いによる除影の特徵を多く抽出して いると考えられる。そのほか，上瞼（一重，二重），鼻孔 の大きさなどの特徴がみられた。

第 3 主成分の特徵 図 5 の第 3 主成分差分画像 (d) に おいて顔上部と顔下部に明度が高い箇所が分かれているこ と，画像 (b)(c) の陰影の特徵などから，上下照明の違いに よる陰影の特徴を多く抽出していると考えられる。そのほ か，第 3 主成分は眉の濃さ，上瞼（一重，二重），目輪郭 および目周辺の濃度，鼻尖の形などの特徵がみられた。

第 4 主成分の特徵 第 4 主成分は眉の濃さ，目，鼻輪 郭の濃度に特徴があった。

以上のように上位主成分には主に照明による顔の院影の 特徵が抽出されたほか，137点の特徵点情報だけでは正規化 しきれない各部位の細かな形状や濃度の違いが現れた。こ のような上位主成分の特徽は, 男性顔画像集合に適用した 場合も同様であった。 
人種評価との関連第 3 主成分において主成分スコア と人種評価得点との相関係数值が $-0.53(p<0.01)$ となり中 程度の負の相関がみられ，第 4 主成分においては相関係数 值 $0.29(p<0.01)$ の弱い正の相関がみられた。第 3 主成分 は人種的顔印象をある程度抽出した基底テクスチャとなっ ていると考えられる。

\subsection{2 属性值付加 PCA によるテクスチャ特徵抽出}

図 6 は女性顔画像の正規化テクスチャ集合に対して，属 性值付加 PCA を適用して得られた固有テクスチャおよび 特徵強調画像である。PC No(1〜4) は主成分番号を示し, $\mathrm{PV} \%$ は寄与率， $\sigma_{k}$ (上段) は主成分スコアの標準偏差で ある。 $\sigma_{z k}$ (下段) は属性值要素を除去して再計算した主成 分スコア $z_{k}^{(i)}($ 式 (12)) の標準偏差である。(a) は各主成分に おける固有テクスチャであり，3.4 節で述べた $M$ 次元べク トル $\boldsymbol{v}_{k}$ を画像化したものである。(b)，(c) はこの $\boldsymbol{v}_{k}$ を用い て $q=4.0$ として求められた各主成分における特徽強調画 像，(d) は (b)(c) の差分画像である.

図 6 において第 1 主成分の寄与率は $90 \%$ 以上となった。 これは付加属性值に重みを掛け，非常に大きな分散を持つ 要素を意図的に作り出しているためである。第 1 主成分は この付加属性值の影響を大きく受けた軸となっており，こ の第 1 主成分固有ベクトルから属性值要素を除去した射影 ベクトル $v_{1}$ は, 元の顔空間上で人種印象を捉えた軸となっ ていると考えられる。

第 1 主成分の特徵と人種評価との関連 $\quad z_{1}^{(i)}$ と人種評価 得点 $a_{i}$ との相関係数絶対值は $0.61(p<0.01), z_{1}^{(i)}$ の標準 偏差は 1319.5 となった。これらの值は, 5.3.1 節において 人種特徵成分として求められた第 3 主成分 (図 5) と比較し て大きな值となっており，ょり人種的印象を捉えた主成分 を抽出できたと考えられる。図 5 の第 3 主成分は人種的特 徵と上下照明による影響が混在している。しかし，図6の 第 1 主成分は目眉部分に特徴差が集中し, 上下照明の影響 は第 4 主成分として分離している。人種認知と顔特徵を探 る心理実験においても, 目眉の特徽が人種印象に最も影響 を与えることが示唆されている ${ }^{1)}$. 図 6 の第 1 主成分 (b)(c) は上瞼 (一重, 二重), 目頭 (蒙古ひだ), 眉下の陰影 (彫 の深さ), 眉の濃さなどの人種顔印象の違いをよく表現し ていると考える。男性顔画像集合に適用した場合も同様に, 第 1 主成分には目眉部分の特徵が集約され, 人種評価得点 との相関も従来法の PCA と比較して大きくなった。

第 2, 3 主成分の特徵 図 6 の第 2 および第 3 主成分 は, 図 5 の第 1 および第 2 主成分とほぼ同様の特徵となっ た。

正規化テクスチャは顔形状としてはほぼ一定であるが, 細 部の形状の違い, 皮膚のひた，体毛の濃さ，彫の深さによ る陰影の特徴などの他に, 照明の違いによる特徴も表現し ている。従来法のPCA ではこれらが混在した特徴として 主成分が抽出されたが，属性值付加 PCAによって，人種印

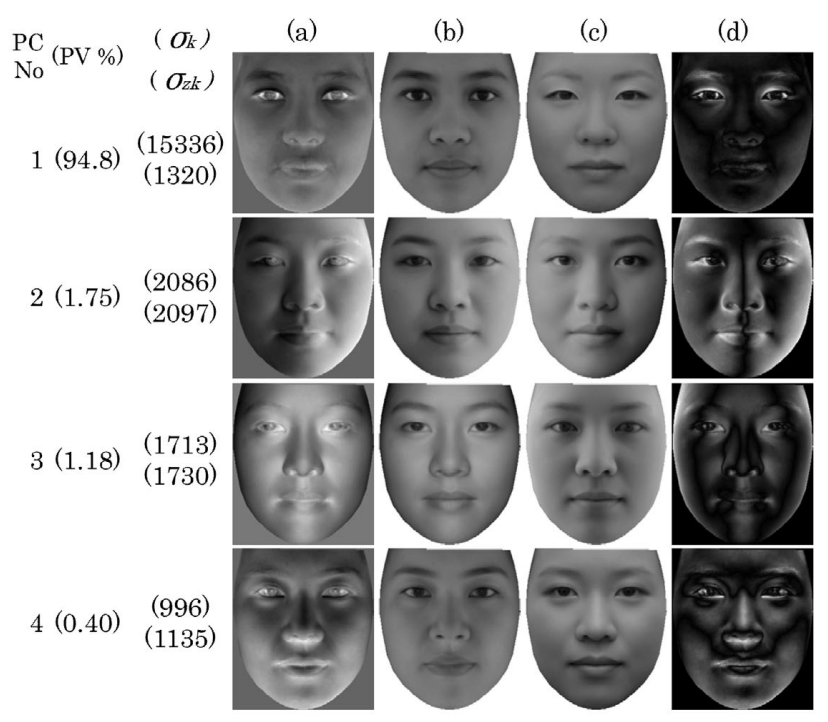

図 6 属性值付加 PCA によって抽出された正規化テクスチャ(女 性) の特徵

Feature of normalized texture extracted by weighted PCA. (female).

象に影響を及ぼす特徵に特化した主成分を第 1 主成分とし て抽出できたと考える。

\section{4 形状特徵の抽出}

本実験では，男性顔画像（日本人，夕イ人各 50 枚計 100 枚）と女性顔画像（日本人，夕イ人各 50 枚計 100 枚）を分 けて，それぞれの形状べクトル集合に対して従来法の PCA および属性值付加 PCA を適用した。以降，女性顔画像集 合からの特徵抽出を例に結果と考察を述べる.

\subsubsection{PCA による形状特徵抽出}

図 7 は女性顔画像の形状べクトル集合に対して, 従来法 のPCA を適用して得られた固有形状および特徴強調形状 である.PC No(1４) は主成分番号を示し，PV\% は寄与 率， $\sigma_{k}$ は主成分スコアの標準偏差である。(a) は各主成分 における固有形状であり, 平均特徽点座標を起点として固 有べクトルの方向と大きさを矢印で示した，各主成分にお ける特徴強調形状 (b)(c) は, それぞれ式 (9)(10) において $q=4.0$ として求められた特徽点座標值を直線で繋ぎ, 線画 として示した。本実験では，これら (a)～(c) の画像から各 主成分において抽出された特徵を検討した。

第 1 主成分の特徵 図 7 の第 1 主成分 $(a)(b)(c)$ の画像 から, 顔輪郭と鼻背の長さ, 口の上下位置, 鼻や眉の形な どの特徴がみられた。

第 2 主成分の特徵 図 7 の第 2 主成分 $(a)(b)(c)$ の画像 から, 顔輪郭と顎の横幅, 鼻尖の形, 眉および唇の形（上 方凸湾，下方凸湾）などの特徴がみられた。第 2 主成分は 顔の上下向きによる影響も考えられる。

第 3，4 主成分の特徵図 7 の第 $3 ， 4$ 主成分 (a)(b)(c) の画像から，顔の左右向きによる鼻・ 口の位置・形状の違 い, 顔幅や唇の厚さなどの特徵がみられた。

以上のように，上位主成分には主に顔幅・顔高および顔 向きの影響が大きく現れた。このような上位主成分の特徵 

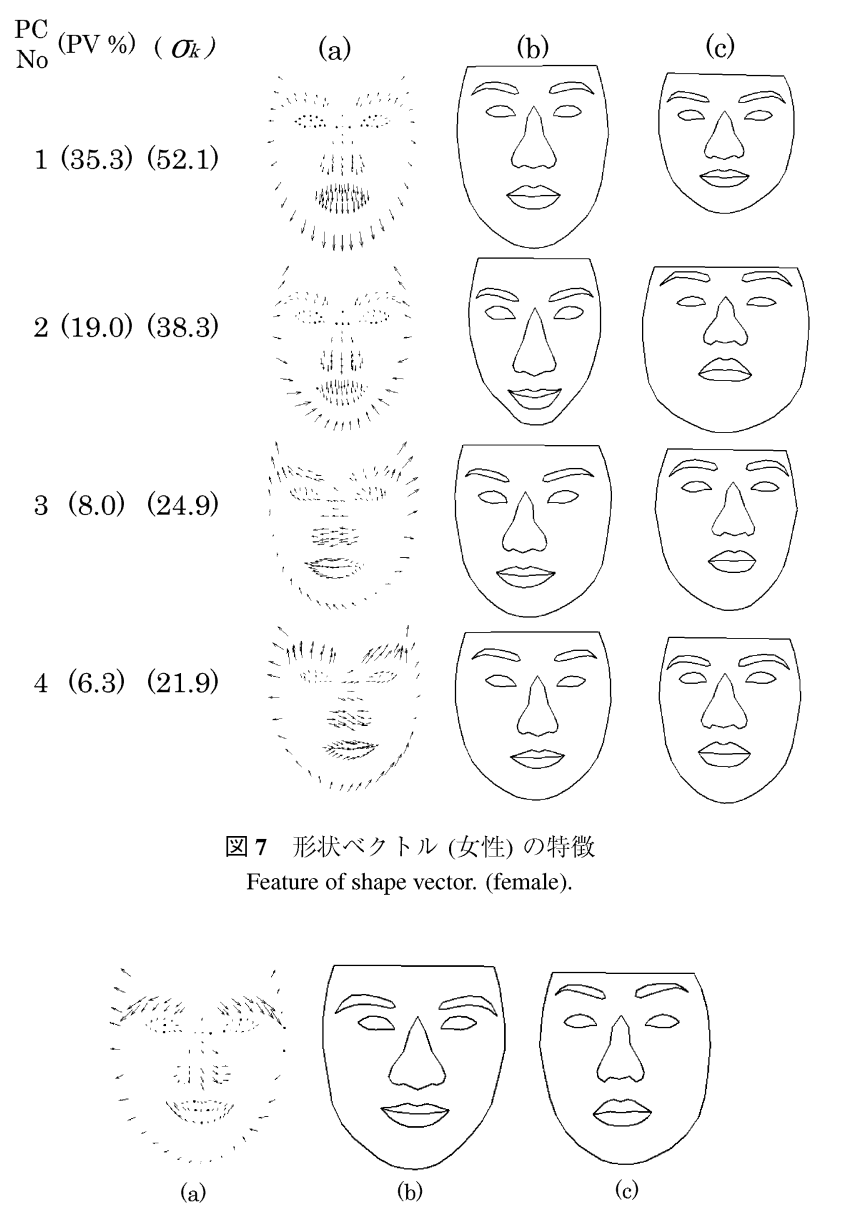

図 8 形状ベクトル (女性) における第 5 主成分の特徽 Feature of the 5 th principal component. (Shape vector of female).

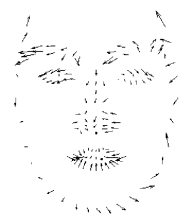

(a)

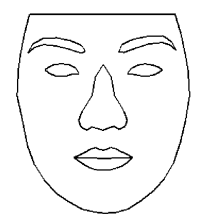

(b)

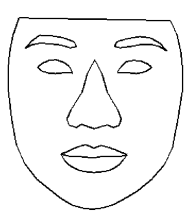

(c)
図 9 形状ベクトル (女性) に扔ける第 15 主成分の特徵 Feature of the 15th principal component. (Shape vector of female).

は，男性顔画像集合に適用した場合も同様であった。

人種評価との関連上位主成分には, 主に, 顔幅・顔 高および顔向きの影響が大きく現れたが，主成分スコアと 人種評価得点との間に有意な相関は認められなかった ( 1 $\%$ 水準)。ただし，第 5 主成分 $\left(\mathrm{PV}=4.5 \% ， \sigma_{5}=18.6\right)$ に扮 いて人種評価得点との相関係数值が $-0.35(p<0.01)$, 第 15 主成分 $\left(\mathrm{PV}=0.8 \%, \sigma_{15}=8.0\right)$ に扔いて人種評価得点と の相関係数值が $0.31(p<0.01)$ となった. 図 8,9 に第 5 拉よび第 15 主成分固有形状 (a) と特徵強調形状 (b) (c) を示 す。第 5 主成分は眉の上下の位置（目と眉の距離）, 眉の 形に特徵があり, 第 15 主成分は目の大きさ, 鼻幅, 唇の厚 さに特徵がみられた。これらの主成分は人種的顔特徽を多 少含んでいるものと考えられる。

\subsection{2 属性値付加 PCA による形状特徵抽出}

図 10 は, 女性顔画像の形状ベクトル集合に対して, 属

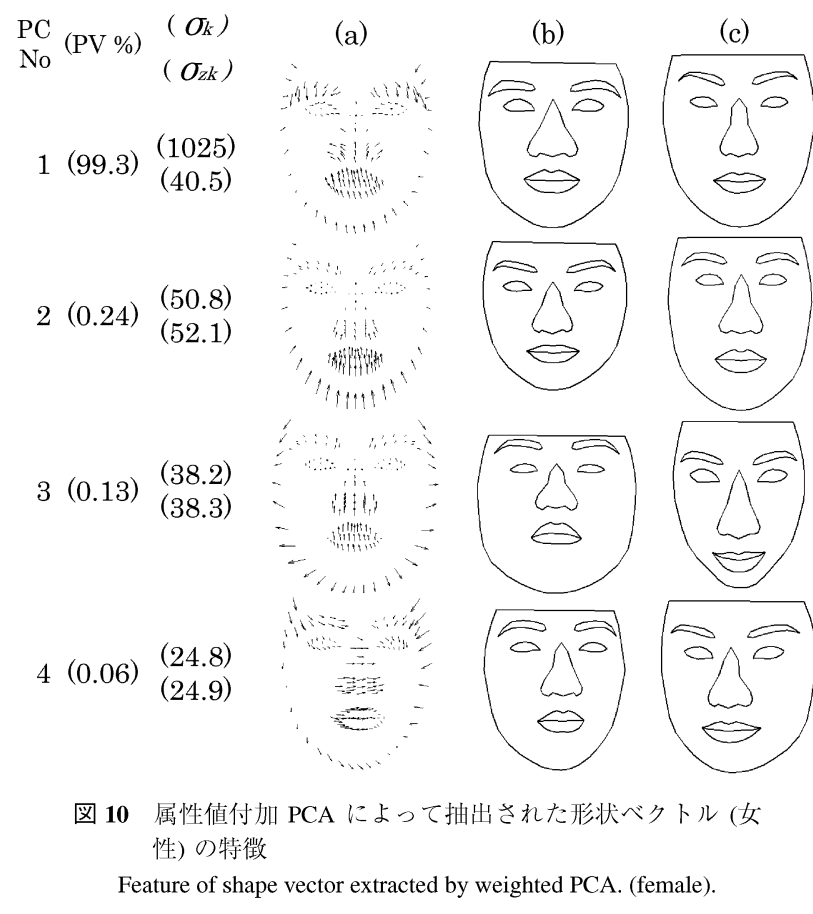

性值付加 PCA を適用して得られた固有形状戈よび特徽強 調形状である．PC No(1〜4) は主成分番号を示し，PV\%は 寄与率， $\sigma_{k}$ (上段）は主成分スコアの標準偏差である。 $\sigma_{z k}$ （下段）は属性值要素を除去して再計算した主成分スコア $z_{k}^{(i)}($ 式 (12)) の標準偏差である. (a) は各主成分に抢ける固 有形状であり, 3.4 節で述べた $M$ 次元ベクトル $\boldsymbol{v}_{k}$ を平均 特徴点座標を起点とした矢印で示した（b)，(c) はこの $\boldsymbol{v}_{k}$ を用いて $q=4.0$ として求められた各主成分に抢ける特徵 強調形状である。

第 1 主成分の特徵と人種評価との関連 $z_{1}^{(i)}$ と人種評価 得点 $a_{i}$ との相関係数絶対值は $0.41(p<0.01), z_{1}^{(i)}$ の標準 偏差は 40.5 となった。これらの值は, 5.4.1 節において人 種特徽成分として求められた第 5,15 主成分 (図 8，9) と 比較して大きな値となって㧍り，より人種的印象を捉えた 主成分を抽出できたと考えられる。図 8 は，人種的顔特徵 以外に顔の向きの影響が混在した特徵となっている。しか し，属性值付加 PCA によって求められた図 10 の第 1 主成 分は, 顔向きの影響がなく, (b) の画像は南方モンゴロイド 的な丸顔で平たい鼻などの特徵がみられ，(c)の画像は北方 モンゴロイド的なやや平坦な顔の特徽がみられた。男性顔 画像集合に適用した場合も第 1 主成分に同様の特徵がみら れ，人種評価得点との相関も従来法の PCA と比較して大 きくなった。

第 2 4 主成分の特徵 図 10 の第 $2 \sim 4$ 主成分は, 図 7 の第 $1 \sim 3$ 主成分とほほ同様の特徵となった.

\section{6. 印象变換実験}

本実験では，属性值付加 PCAによって得られた特徵べク トル $\boldsymbol{v}_{1}$ の有効性を検証するため，3.5 節で述べた手法を用 いて人種印象变換操作を行った。男性顔画像（日本人, 夕 


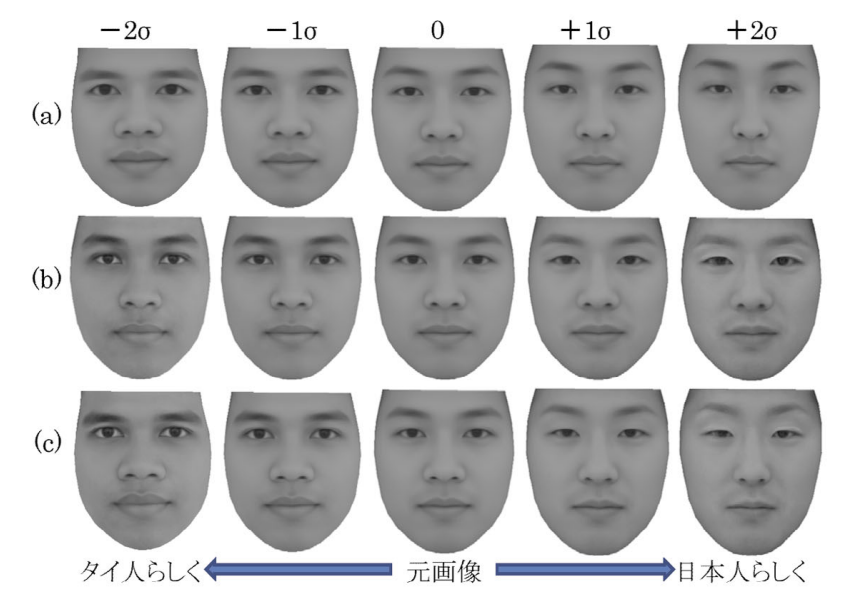

図 11 男性平均顔を元画像とした人種印象変換

Racial impression conversion images of faces using extracted features. (male).

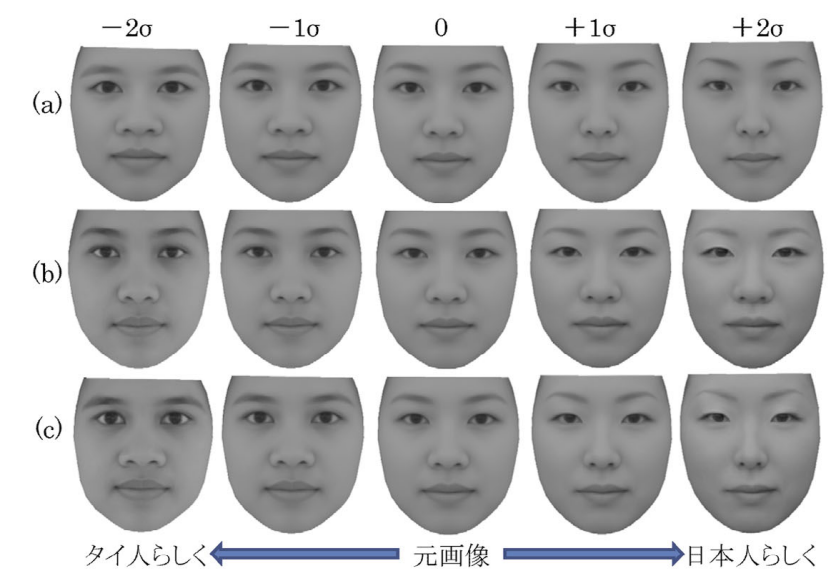

図 12 女性平均顔を元画像とした人種印象変換 Racial impression conversion images of faces using extracted features. (female).

イ人各 50 枚計 100 枍）と女性顔画像（日本人, 夕イ人各 50 枚計 100 枚）を用いて男性平均顔と女性平均顔を作成し, 印象変換の元画像とした。図 11 は男性平均顔を, 図 12 は 女性平均顔を元画像とした印象変換結果である. (a) は形状 ベクトル，(b) は正規化テクスチャ, (c) は正規化テクスチヤ と形状ベクトルの双方を用いた印象変換であり, 式(13)の 変換重み係数 $h$ を- $2.0 \sim+2.0$ の範囲で変化させた.

\section{1人種印象評定実験}

本実験では, 印象変換操作の有効性を検証するため, 得 られた印象変換画像に対する人種印象評定実験を行った。

\subsection{1 方 法}

\section{(1) 実験刺激}

刺激顔画像としては，図 11，12 に示した画像を含む，男 性平均顔扔よび女性平均顔を元画像として変換重み係数 $h$ を-2.0 +2.0 の範囲で 0.5 刻みで変化させた印象変換画像 50 枚を用いた。

\section{(2) 被験者}

被験者は 25 名の日本人大学生であった。

\section{(3) 手続き}

実験プログラムは，ディスプレイに刺激顔画像を提示し，

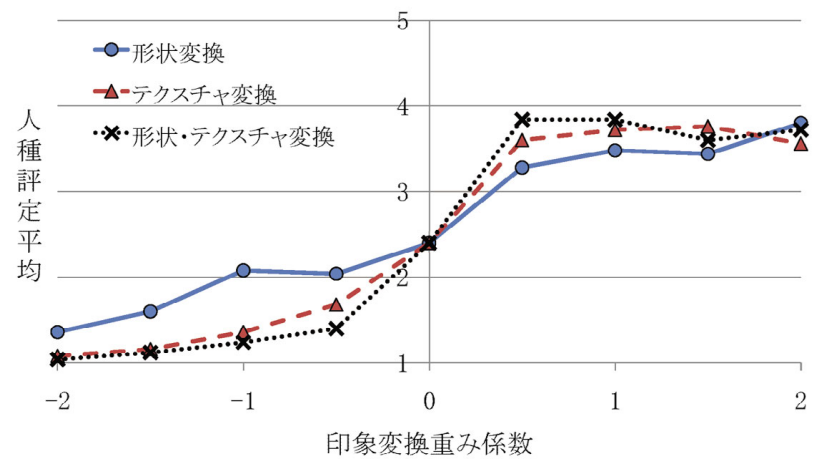

図 13 人種評定平均と変換重み係数值の関係（男性平均顔に対 する印象変換)

Relation between rating average and conversion weight value. (male).

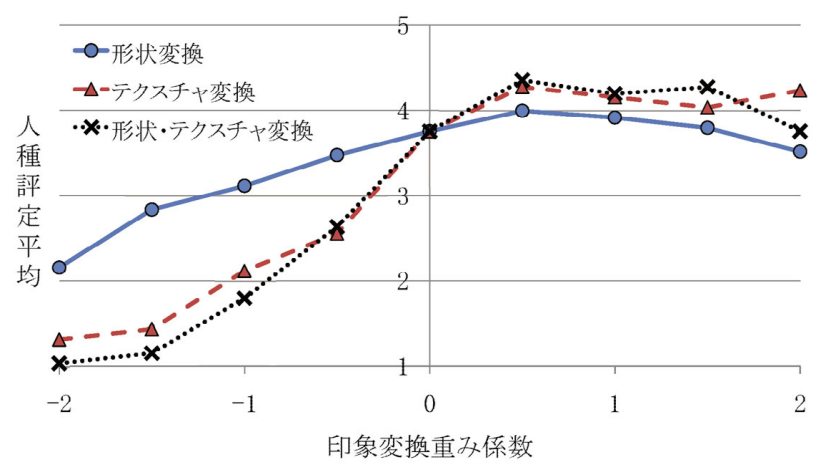

図 14 人種評定平均と变換重み係数値の関係（女性平均顔に対 する印象変換)

Relation between rating average and conversion weight value. (female).

被験者に顔画像の人種を判断させ,「東南アジア系 (1 点)」 「どちらかというと東南アジア系 (2 点)」「どちらともいい がたい ( 3 点)」「どちらかというと日本人 ( 4 点)」「日本人 ( 5 点)」の 5 段階評定をラジオボタンによって選択させた. 確認ボタンクリック後に次の刺激顔画像を提示し, 同様の 課題を刺激顔画像の枚数分繰り返させた。提示する刺激顔 画像の順番はランダムであり, 制限時間は設けなかった。

\subsection{2 結果と考察}

図13，14 は，被験者 25 名による印象变換画像に対する 人種評定平均である。図 13 は男性平均顔を，図 14 は女性 平均顔を元画像とした印象変換画像に対する評定結果であ り, 変換重み係数負方向を夕イ人方向, 正方向を日本人方 向への印象変換として示した。3 種類の印象変換方法（形 状変換，テクスチャ変換，形状・テクスチャ変換）ごとに各 印象変換画像の人種評定平均について分散分析を行った結 果，いずれの場合も変換重み係数値の違いによる有意差が みられた $(p<.001)$. Ryan 法を用いた多重比較によれば, 図 14 の形状変換の場合を除いて, 変換重み係数 -0.5 と +0.5 の印象变換画像間で人種評定平均に大小関係があり( $5 \%$ 水 準), 人種判断が変化した.

以上の結果から,「テクスチャ変換」扔よび「形状・テクス チャ変換」に関しては, 男女平均顔ともに人種的印象の変 化が見られ，属性值付加 PCA によって得られた特徽は人種 認知に有効な特徵であることが示唆された。しかし，女性 
平均顔の形状変換に関しては, 人種印象に及ぼす影響が他 の場合と比較して小さかった。男性平均顔に関しては形状 変換のみでも人種印象の変化がみられた。この結果は, 5.2 節で述べたように, 形状特徴においては男性の方が人種評 価得点との相関が高かったこと (図 4) と矛盾しない結果で あったと考える。

\section{7. むすび}

本研究では, 同じアジア人であり人種的に近い日本人と 夕イ人の顔画像を用いて, 日本人と夕イ人の人種的印象に 影響を及ぼす顔特徵の違いを PCA によって抽出・分析し た. 顔特徵をテクスチャ情報と形状情報に分離し，それぞ れについて心理実験による人種印象評価と関連する特徵を PCA によって抽出・分析した.PCA による特徴抽出は，従 来法と向田らが提案した属性值付加 PCA による手法を比 較検討した。

従来法の PCA をテクスチャ情報と形状情報に適用した 実験において, 主成分スコアと人種評価得点との相関係数 值から人種印象評価と関連する主成分を選択し, 強調顔画 像を用いて抽出された特徵を分析した。この実験で抽出さ れた顔特徵は, テクスチャ情報においては照明の影響, 形 状情報においては顔向きなどの情報が混在していたが，人 種印象特徵をある程度表現している主成分が抽出できた.

顔特徵べクトルに「重み付けをした人種評価得点」を付 加して PCA を行った実験において, 重みをある程度大きな 值に設定することによって, 人種顔印象特徽を第 1 主成分 として抽出することができた。この実験で，第 1 主成分ス コアの標準偏差および人種評価得点との相関が, 従来法の PCA で抽出された人種特徵成分より大きくなり, 従来法の PCA と比較して, より人種印象に特化した顔特徴を抽出で きたと考える。

属性值付加 PCA によるテクスチャ情報からの特徽抽出 では，照明の違いによる影響が軽減され目眉部分に集約さ れた人種顔印象特徴を第 1 主成分として抽出できた.

属性值付加 PCA による形状情報からの特徵抽出では, 顔 向きの違いによる影響が軽減され, 従来法の PCA では複 数の主成分に分散していた人種顔印象特徵が第 1 主成分に 集約された。

さらに, これらの得られた特徴成分を用いて, 人種印象 変換操作を行った。この結果, 人種的印象の変化が見られ, 属性值付加 PCA から得られた特徵は, 人種認知に有効な 特徴であることが示唆された。

従来の PCA による顔特徵抽出において, 顔特徵として 得られた主成分には各部位の形状や配置の違い, 皮膚のひ た，体毛の濃さなどのほかに，照明による影響や顔向きの 微妙な違いによる特徵も混在していた。本研究で行った形 状情報とテクスチャ情報を分離した属性值付加 PCA によっ て, 照明や顔向きによる影響を軽減し, 所望の顔特徵成分 に特化した主成分を抽出できたと考える。本手法は, 人種
印象に限らず性別や年齢，その他の高次印象に影響を及ぼ す顔特徵を抽出する手段として有効であると考える．顔印 象に影響を及ぼす顔特徵を抽出することは，目撃情報など の印象語をキーワードとした顔画像検索システムへの応用 などに示唆を与えることにもなる。

今後は人種のカテゴリを増やし，より一般的な視点での 分析が必要であろう.さらに, 性別や年齢, 魅力, その他 の高次印象など様々な顔印象への適用や, 人種自動推定な どの応用を目指したい.

\section{〔文献〕}

1）秋葉将和，チャロトーンリュウチャワリット, 菅野 恒雄, 長尾 智晴: “日 本人と夕イ人の顔の人種 - 性別認知に関する検討”, 映情学誌, $\mathbf{6 4}, 4$, pp.611-621 (2010)

2) Chalothorn Liewchavalit, Masakazu Akiba, Tsuneo Kanno and Tomoharu Nagao: “Extracted Facial Feature of Racial Closely Related Faces", Proc. of 2010 The 2nd International Conference on Digital Image Processing (ICDIP 2010), February 26-28, Singapore (2010)

3) M.Turk and A.Pentland : “Eigenfaces for recognition ”, Journal of Cognitive Neuroscience, 3, 1, pp.71-86 (1991)

4）向田茂, 安藤広志, 木下敬介, 蒲池みゆき, 千原國宏:“顔画像生成のため の統計的な年齢特徵抽出”, 日本顔学会誌, 2, 1, pp.15-24（2002）

5）深田 陽子, 山口 泰: “年齢相応な顔の魅力操作法”，信学論， J92-D, 8, pp.1166-1175 (2009)

6）小林敏和，大眓正孝，大竹俊輔，赤松茂: “形状,テクスチャ空間にお ける線形判別関数を用いた顔画像の印象変換: 年齢・性差に関する印象变 換の評価”，信学技報 IE， 103, 644,pp.7-12（2004）

7）瀧川 えりな, 細井聖, 川出雅人:“顔画像による人種推定技術”, 信学 技報，PRMU，103，452，pp.19-24（2003）

8) HANIHARA K. : "Dual structure model for the population history of the Japanese population ”, Japan Review, 2, pp.1-33 (1991)

9）埴原和郎:“日本人の顔 小顔・美人顔は進化なのか”, 講談社（1999）

10）在京タイ王国大使館：“タイ王国について：http://www.thaiembassy. jp/rte1/content/view/80/116/”, (2006)

11）大林太良 (編集):“民族の世界史 6 東南アジアの民族と歴史”，山川出 版社 (1984)

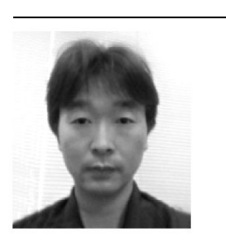

票秋葉 将和 1998 年, 職業能力開発総合大学校 情 報工学科卒業. 2000 年, 同大学校研究課程工学研究科修 了. 同年, 雇用能力開発機構勤務. 2007 年〜現在, 職業 能力開発総合大学校情報システム工学科講師. 2011 年, 横浜国立大学大学院環境情報学府博士後期課程修了。主 にパターン認識, ヒューマンインフォメーションに関す る研究に従事. 博士 (工学). 正会員.

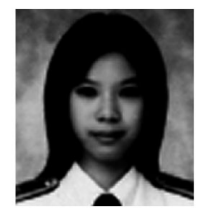

チャロトーンリュウチャワリット 2006 年, 職業能力開発総合大学校情報システム工学科 卒業. 同年，夕イ労働省技能開発局勤務. 2010, 職業能 力開発総合大学校研究課程工学研究科修了. 主に, 顔と ヒューマンコミュニケーションに関する研究に従事.

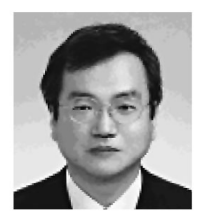

㔖芦野 恒雄 1975 年, 職業訓練大学 (現在, 職業能 力開発総合大学校) 電子科卒業. 同年, 同大学校勤務. 現 在, 情報システム工学科教授. 主にパターン認識, 画像 処理, ヒューマンコミュニケーションに関する研究に従 事. 工博. 正会員.

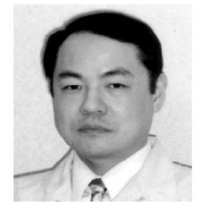

長尾 智晴 1985 年, 東京工業大学大学院博士後期 課程中退. 同年, 同大学工学部付属像情報工学研究院施 設助手. 1995 年, 同大学工学部付属像情報工学研究院施 設助教授. 2001 年, 横浜国立大学大学院環境情報研究院 教授. 工博. 正会員. 